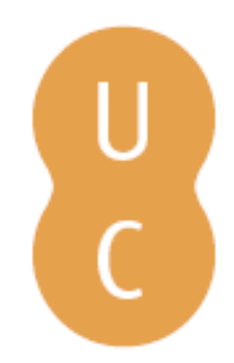

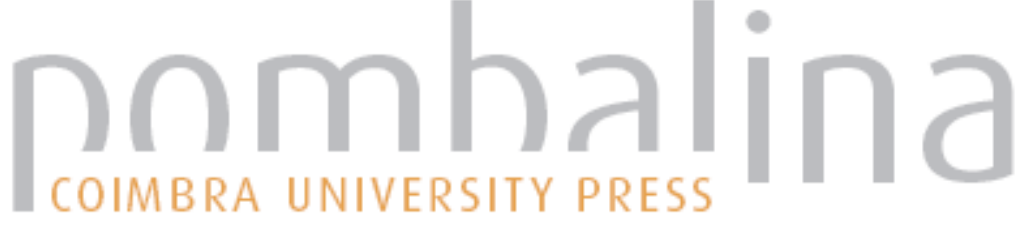

\section{Cinco séculos da Biblioteca Geral}

Autor(es): $\quad$ Martins, Guilherme de Oliveira

Publicado por: Imprensa da Universidade de Coimbra

URL persistente:

URI:http://hdl.handle.net/10316.2/36992

DOI:

DOI:http://dx.doi.org/10.14195/978-989-26-1045-0_21

Accessed : $\quad$ 26-Apr-2023 15:59:40

A navegação consulta e descarregamento dos títulos inseridos nas Bibliotecas Digitais UC Digitalis, UC Pombalina e UC Impactum, pressupõem a aceitação plena e sem reservas dos Termos e Condições de Uso destas Bibliotecas Digitais, disponíveis em https://digitalis.uc.pt/pt-pt/termos.

Conforme exposto nos referidos Termos e Condições de Uso, o descarregamento de títulos de acesso restrito requer uma licença válida de autorização devendo o utilizador aceder ao(s) documento(s) a partir de um endereço de IP da instituição detentora da supramencionada licença.

Ao utilizador é apenas permitido o descarregamento para uso pessoal, pelo que o emprego do(s) título(s) descarregado(s) para outro fim, designadamente comercial, carece de autorização do respetivo autor ou editor da obra.

Na medida em que todas as obras da UC Digitalis se encontram protegidas pelo Código do Direito de Autor e Direitos Conexos e demais legislação aplicável, toda a cópia, parcial ou total, deste documento, nos casos em que é legalmente admitida, deverá conter ou fazer-se acompanhar por este aviso. 

Tendo como pano de fundo as Comemorações dos seus 500 anos, a Biblioteca Geral da Universidade de Coimbra organizou um Congresso Internacional subordinado ao tema "A Biblioteca da Universidade: permanência e metamorfoses", que teve lugar nos dias 16, 17 e 18 de janeiro de 2014, no auditório da Reitoria da Universidade de Coimbra.

O objetivo maior desta reunião científica foi o de refletir sobre o presente e o futuro das bibliotecas que servem públicos universitários. Numa outra vertente, procurou chamar-se a atenção para a importância de que a Biblioteca se reveste, tendo em vista o progresso do conhecimento técnico e científico. Por último, o Congresso pretendeu instituir-se como oportunidade de reflexão prospetiva e como lugar de encontro entre as sensibilidades de todos os que trabalham profissionalmente com livros e com outros suportes de natureza bibliográfica.

Nesse sentido, foram apresentadas Conferências, Mesas Redondas e sessões de Testemunhos em torno de temas como o valor das bibliotecas universitárias, a biblioteca universitária em contexto; as mudanças e os desafios; a biblioteca universitária e a sociedade da informação e conhecimento; o impacto do acesso aberto na comunidade científica, e as bibliotecas digitais. 
GUILHERME DE OLIVEIRA MARTINS

Tribunal de Contas

\section{CINCO SÉCULOS DA BIBLIOTECA GERAL}

Cinco séculos de uma Biblioteca é tempo de memória e de reconhecimento. Conheço muito bem a Biblioteca Geral da Universidade de Coimbra, o seu valor e prestígio. Aí se encontra, aliás, o escritório e um núcleo fundamental da biblioteca de Oliveira Martins, que assim ficou associado para sempre à Universidade, apesar de ser um dos únicos membros da chamada Geração de Setenta que não frequentou a Alma Mater. Passei longas e aprazíveis tardes nesse lugar de exceção, graças à amizade e generosidade do meu saudoso amigo Professor Aníbal Pinto de Castro. E sei muito bem como estes quinhentos anos são simbólicos, uma vez que nos reportamos apenas à referência mais antiga que chegou até nós à antiga "livraria do Estudo", através da tão citada ata de 1513, onde se fala, simplesmente, de "consertar uns canos que deixavam entrar água» no lugar onde estavam colocados os livros. O certo é que já antes de 1503 havia «setenta livros de toda ciência que estavam na dita livraria das Escolas Velhas», existindo já cerca de 739 volumes no final da centúria. Fernão Lopes de Castanheda foi guarda do cartório e livraria e os Estatutos de 1591 afirmavam que «uma das cousas mais importantes à Universidade é ter boa livraria, para ela se poder conservar e aumentar» - e o reitor estava obrigado a comprar para o dito acervo «cem cruzados de livros dos que nela não houver, e os melhores e mais proveitosos que no tal tempo se acharem", à custa da Universidade. E não o fazendo assim "perderia a sua fazenda cinquenta cruzados para a dita livraria». Sem uma Biblioteca ou um conjunto de bibliotecas atuais e diversificadas não podemos falar de uma Universidade aberta ao mundo. Hoje discute-se o livro e o seu futuro. Ele não estará em causa. Importa, sim, compreender que 
esse precioso instrumento de cultura está disponível de diversos modos. A verdade é que se lê mais, pelas melhores qualificações das pessoas, mas generalizadamente porventura lê-se pior, sendo que, paradoxalmente, os melhores leitores por certo leem melhor. Eis por que razão celebrar uma biblioteca é saudar o futuro aberto do saber e do progresso. Comemorar cinco séculos da "livraria do Estudo" é celebrar o caminho, a memória, a complexidade, a continuidade, o conhecimento e a compreensão. Estamos, afinal, num centro, por excelência, de saber e comunicação, que hoje se abre à inovação e ao progresso. Quinhentos anos são motivo de exigência e de responsabilidade! 
José Augusto Cardoso Bernardes é Professor da Faculdade de Letras da Universidade de Coimbra e Diretor da Biblioteca Geral da Universidade

Ana Maria Eva Miguéis é coordenadora do Serviço Integrado das Bibliotecas da Universidade de Coimbra

Carla Ferreira é bibliotecária nos Serviços de Biblioteca e Documentação da Faculdade de Letras da Universidade de Coimbra. 


\section{Série Documentos}

Imprensa da Universidade de Coimbra

Coimbra University Press

2015

C •

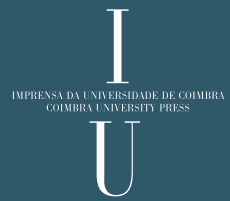

